\title{
Amyotrophic Lateral Sclerosis After Exposure to Manganese from Traditional Medicine Procedures in Kenya
}

\author{
Elin Roos ${ }^{1}$ (D) Sebastian K.T.S. Wärmländer ${ }^{2,3} \cdot$ Jeremy Meyer $^{4} \cdot$ Sabrina B. Sholts ${ }^{5}$ • Jüri Jarvet ${ }^{2,6}$ • \\ Astrid Gräslund ${ }^{2} \cdot$ Per M Roos ${ }^{7,8}$
}

Received: 25 August 2020 / Accepted: 17 November 2020 / Published online: 23 November 2020

(C) The Author(s) 2020

\begin{abstract}
Amyotrophic lateral sclerosis (ALS) is a fatal neurodegenerative disease characterized by motor neuron loss and widespread muscular atrophy. Despite intensive investigations on genetic and environmental factors, the cause of ALS remains unknown. Recent data suggest a role for metal exposures in ALS causation. In this study we present a patient who developed ALS after a traditional medical procedure in Kenya. The procedure involved insertion of a black metal powder into several subcutaneous cuts in the lower back. Four months later, general muscle weakness developed. Clinical and electrophysiological examinations detected widespread denervation consistent with ALS. The patient died from respiratory failure less than a year after the procedure. Scanning electron microscopy and X-ray diffraction analyses identified the black powder as potassium permanganate (KMnO4). A causative relationship between the systemic exposure to $\mathrm{KMnO} 4$ and ALS development can be suspected, especially as manganese is a well-known neurotoxicant previously found to be elevated in cerebrospinal fluid from ALS patients. Manganese neurotoxicity and exposure routes conveying this toxicity deserve further attention.
\end{abstract}

Keywords Amyotrophic lateral sclerosis $\cdot$ Manganese $\cdot$ Neurodegeneration $\cdot$ Potassium permanganate $\cdot$ Traditional medicine

Elin Roos

elin.roos@ki.se

1 Department of Global Public Health, Karolinska Institutet, 171 77 Stockholm, Sweden

2 Department of Biochemistry and Biophysics, Stockholm University, 10691 Stockholm, Sweden

3 UCLA/Getty Conservation Programme, Cotsen Institute of Archaeology, UCLA, Los Angeles, CA 90095, USA

4 Unit for Surgical Research, Medical School of Geneva, University of Geneva, 120511, 14 Genève, Switzerland

5 Department of Anthropology, National Museum of Natural History, Smithsonian Institution, 370 12, Washington D.C, USA

6 The National Institute of Chemical Physics and Biophysics, 12618 Tallinn, Estonia

7 Institute of Environmental Medicine, Karolinska Institutet, 171 77 Stockholm, Sweden

8 Department of Clinical Physiology, St. Goran Hospital, 112 81 Stockholm, Sweden

\section{Introduction}

Amyotrophic lateral sclerosis (ALS) is a fatal neurodegenerative disorder characterized by loss of upper and lower motor neurons and sclerosis of motor pathways in the spinal cord, leading to widespread progressive skeletal muscle atrophy [1] and death by respiratory failure. Electrophysiological examinations are necessary in the diagnostic workup of ALS, as ALS-mimicking disorders exist, most commonly in the form of myopathic conditions [2]. The ALS incidence is about 3 per 100000 person-years [3], with a peak age of diagnosis at 54 years and a projected incidence increase in coming years [4]. Around $50 \%$ of the patients die within 30 months after symptom onset, while around $20 \%$ may survive up to 10 years [5]. Several hypotheses for ALS pathogenesis have been proposed.

The notion that increased cellular oxidative stress contributes to ALS is supported both by observations from post-mortem ALS tissues, where widespread accumulation of oxidative damage to proteins, lipids, and DNA have been noted [6], and by studies showing that superoxide dismutase (SOD1) mutations are related to increased protein and lipid oxidation [7]. A related putative ALS cause is aggregation of misfolded SOD proteins [8]. Aberrations in chromosome 9 (C9orf72) with nucleotide 
repeats and hyperphosphorylated tau protein observed in sporadic ALS have also been proposed as potentially causative [9], as has mRNA dysmetabolism [7]. Markers of inflammation are elevated in ALS [10], and the hypothesis that inflammation plays a causative role in ALS is strengthened by observations of activated macrophages and the presence of dendritic cells in ALS spinal cord tissue [11]. A fifth possibility is that metals with neurotoxic or/and redox-cycling properties act as triggers for oxidative stress and neuroinflammation $[12,13]$.

The interplay between genetic and environmental risk factors for ALS is likely complex and has been extensively discussed for several decades. Cigarette smoking [14], pesticide exposure, and advanced age are known risk factors $[15,16]$, and a recent thorough meta-analysis of ALS occupational risk factors brought metal exposure to the fore [17]. Manganese (Mn) [18] and lead ( $\mathrm{Pb})$ [19] have been specifically implicated in ALS pathogenesis [20, 21]. Adding to this search for causative factors in ALS, we present here a case of a patient who developed ALS shortly after subcutaneous exposure to a metal powder during a traditional medicine procedure in Kenya.

\section{Case Report}

A 56-year-old previously healthy military photographer from the Kisii region in Kenya sought medical attendance for lower back pain. After 8 months of unsuccessful treatments with non-steroidal anti-inflammatory drugs, he consulted a local spiritualist and herbalist in Kisii. This region is known for its long history of active use of traditional medicine, defined as "the knowledge, skills and practices based on the theories, beliefs and experiences indigenous to different cultures, used in the maintenance of health and in the prevention, diagnosis, improvement or treatment of physical and mental illness"

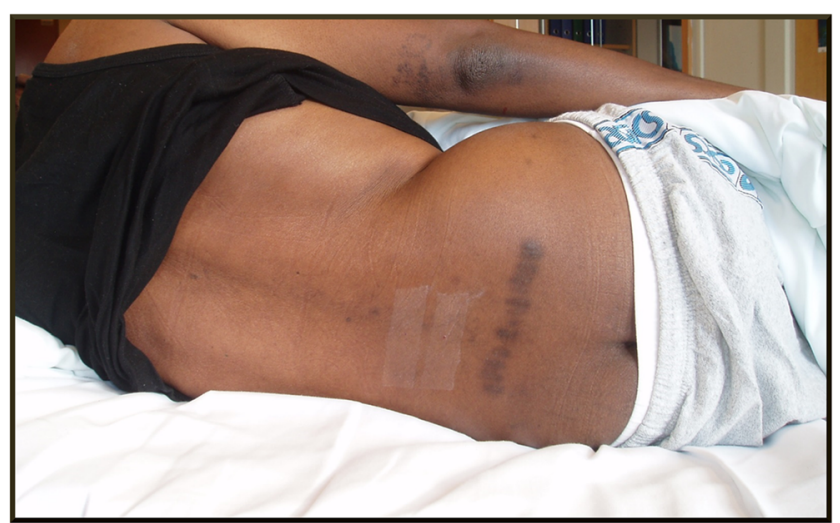

Fig. 1 The studied patient with multiple parallel lumbar scars from the ogosaraka scarification procedure. Photo by P.M.R
[22]. The patient then underwent a traditional medicinal procedure involving lower back scarification known as Ogosaraka in the local Kisii language (personal communication from the patient's family). Along a line connecting the posterior iliac spines in the lumbar region, several sagittal cutaneous incisions were cut in parallel with a sharp razor blade (Fig. 1), and a glistening black metal powder (Fig. 2a) was inserted into the open wounds.

About 4 months after the scarification procedure, the patient still suffered continuous lumbar pain, and magnetic resonance imaging found a herniated lumbar disc at level L4/L5 and L5/ S1. Symmetrical muscle weakness in the legs, arms, and neck developed slowly followed by head drop. Progressively he developed widespread muscle weakness and could hardly walk or carry heavy objects. He had difficulties coughing, lost weight, and displayed distinct generalized muscle atrophy. Routine bloodwork was normal, and a liver ultrasonography performed due to slightly elevated liver enzymes was also reported as normal. About 7 months after the scarification procedure, the patient sought healthcare at Oslo University Hospital in Norway, where a complete neurological assessment including a clinical neurological examination performed by a specialist in neurology indicated ALS. A neurophysiological examination with neurography and electromyography showed fibrillation potentials and positive sharp waves in several investigated skeletal muscles, including the glossus muscle, and concluded with widespread axonal damage and denervation consistent with ALS. The ALS diagnosis was confirmed by two specialists in neurology. The patient died from respiratory failure about 10 months after the scarification procedure.

\section{Materials and Methods}

A sample of a metal powder used in the scarification procedure was collected by the patient's daughter and transferred from Kenya to the Department of Biochemistry and Biophysics at Stockholm University in Sweden for analysis. A Hitachi TM-3000 scanning electron microscope (SEM), operating at $15 \mathrm{kV}$ and equipped for elemental analysis via energy-dispersive spectroscopy (SEM-EDS), was used to characterize the shape and chemical composition of the powder particles. These investigations were performed at high vacuum $\left(10^{-5}\right.$ Torr $)$ without surface coating or other sample preparation. An X'Pert-PRO X-ray powder diffractometer from PANalytical B.V. (The Netherlands), operating at 40 $\mathrm{mA} / 45 \mathrm{kV}$ and running the sample for two hours, was used to record X-ray diffraction (XRD) data for the powder. The SEM data was analyzed using the Quantax 70 software (Bruker, Germany), while the X-ray diffractogram was processed and analyzed using the X'Pert Data Viewer software (PANalytical, The Netherlands). 
Fig. 2 a Photograph of the black powder particles. b SEM image of the black powder particles at 300 $\mathrm{x}$ magnification. $\mathrm{c}$ Photograph of the black powder dissolved in water. Images by S.K.T.S.W

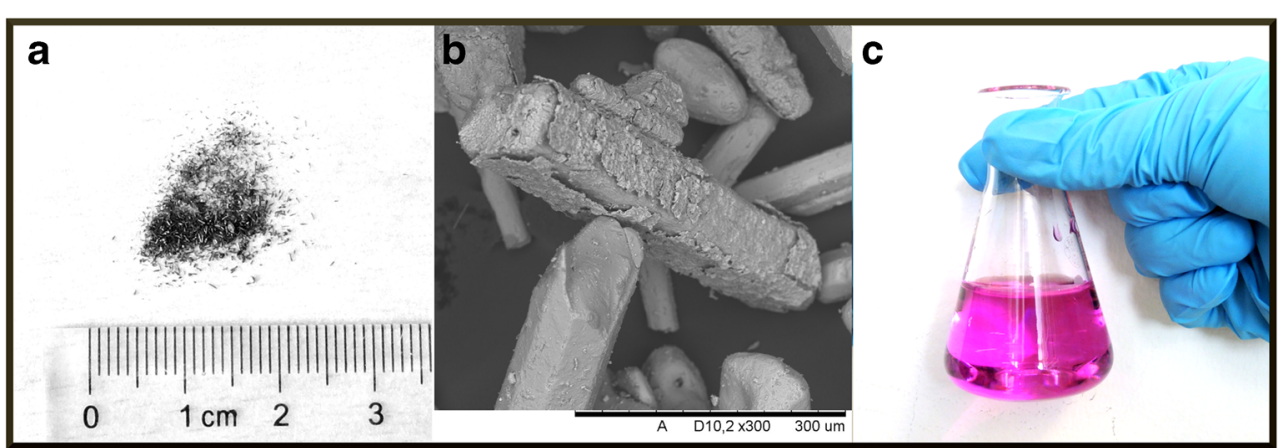

\section{Results}

Scanning electron microscopy images showed that the black glistening powder (Fig. 2a) inserted into the lower back incisions of the patient consisted of particles in the shape of small rods (Fig. 2b). Scanning electron microscopy-energy-dispersive spectroscopy (SEM-EDS) spectra identified the elements $\mathrm{K}, \mathrm{Mn}$, and $\mathrm{O}$ in these rods, roughly in the proportion 1:1:4 (Fig. 3a). When dissolved in distilled water, the black powder produced a solution of violet color (Fig. 2c). These observations taken together indicated that the powder was pure potassium permanganate $\left(\mathrm{KMnO}_{4}\right)$. This was confirmed by XRD analysis, where the recorded diffractogram showed a perfect match with reference data for $\mathrm{KMnO}_{4}$ crystals (Fig. 3b). The latter analysis confirmed also that even though SEM-EDS analysis is useful when characterizing unknown materials [23-28], it is only the combination with XRD analysis that allows for unambiguous identifications of inorganic compounds [29-33].

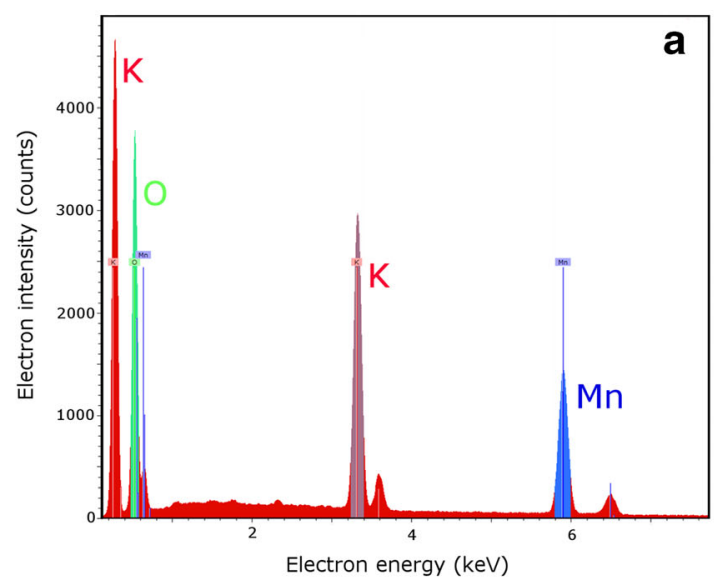

Fig. 3 a SEM-EDS spectrum of the black powder, identifying the elements K, Mn, and O. b X-ray diffractogram of the black powder. The peaks in the spectrum correspond to the angles where constructive

\section{Discussion}

Metal exposure seems to potentially contribute to ALS pathogenesis [20]. Redox-active ions of metals such as $\mathrm{Cu}$ [34], $\mathrm{Fe}$ [35], $\mathrm{Mn}[18]$, and $\mathrm{Pb}$ [15] appear to be particularly harmful. Such metal ions may act as triggers for cellular oxidative stress, hyperphosphorylation of the tau protein [36], and/or inflammation. To what extent these complex disease mechanisms are induced by metal exposure in the case of ALS remains to be clarified.

The patient was subjected to a scarification procedure where a black powder consisting of pure potassium permanganate $\left(\mathrm{KMnO}_{4}\right.$; Figs. 2 and 3) was inserted into the fresh cuts. In sub-Saharan Africa, it is not uncommon to insert foreign substances into dermal cuts to achieve scarification patterns similar to tattoos $[37,38]$. Scarification can however also be a medical procedure, either as a treatment in itself, or as a way to introduce various substances into the patient's circulation by rubbing them into the wound $[23,39,40]$. Some of these substances, such as toxic minerals or medicinal plants

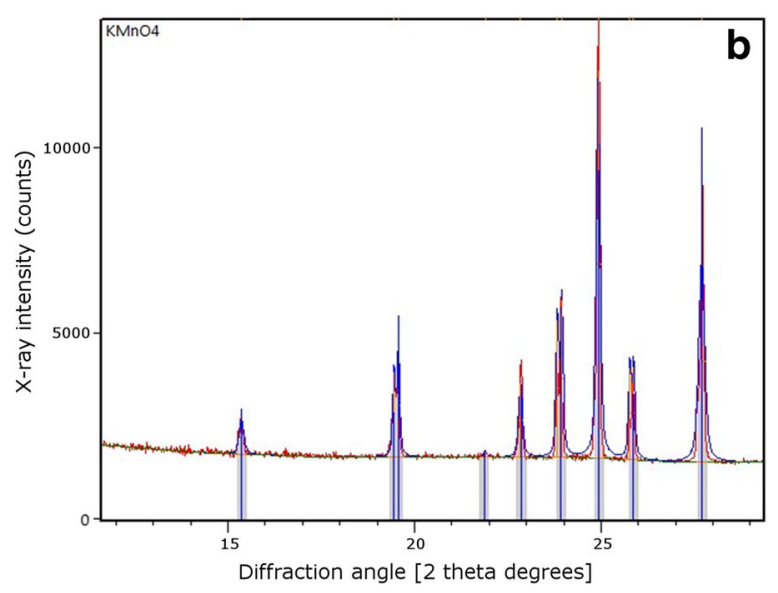

diffraction interference occurs. The observed peaks perfectly match the reference diffraction angles for $\mathrm{KMnO} 4$ crystals (blue lines). Images by S.K.T.S.W 
containing heavy metals, may have negative health effects $[23,41]$. Identifying health risk factors in traditional practices is a growing field of research $[23,42,43]$ of particular importance in Africa, where most people use both modern (Western) and traditional African healthcare [44], where the traditional substances used are largely undocumented [23] and where advocates of the right to choose traditional medicine are gaining momentum [45].

$\mathrm{KMnO}_{4}$ is a well-known disinfectant and a core item on the World Health Organization (WHO) Model List of Essential Medicines [46]. As an antiseptic agent in dermatological medicine, $\mathrm{KMnO}_{4}$ as a dilute aqueous solution is recommended in the healing of suppurating wounds [47]. It does not occur naturally as a salt or mineral but was conceived and patented as a novel chemical disinfectant in the 1850s [48]. Although not a traditional compound, $\mathrm{KMnO}_{4}$ in crystalline form is today widely used by African traditional health practitioners (THPs) [23]. In a recent South African study [49], 99 THPs reported using $\mathrm{KMnO}_{4}$ for patients with skin rash or wounds, 74 used it for aches, 23 for sexually transmitted diseases, and 23 for nervous conditions. The main administration routes were in baths $(n=94)$, by oral ingestion $(n=67)$, and in herbal compresses $(n=66)$, although 25 THPs described that they used $\mathrm{KMnO}_{4}$ through subcutaneous implantation. Sociocultural uses of $\mathrm{KMnO}_{4}$ are generally unregulated and not commonly reported [49], but several hospitals in South Africa have documented $\mathrm{KMnO}_{4}$ misuse, often with detrimental effects [50-53].

Chemically, $\mathrm{KMnO}_{4}$ is a very strong oxidant. In a neutral solution, the $\mathrm{MnO}_{4}{ }^{-}$anion will be reduced to $\mathrm{MnO}_{2}$, while acidic or reducing environments allow full reduction to a free $\mathrm{Mn}^{2+}$ ion, corresponding to an uptake of five electrons [54]. The large oxidizing capacity of the $\mathrm{MnO}_{4}{ }^{-}$anion is the main rationale for its toxicity [55-57]. In addition to the direct oxidative damage induced by $\mathrm{MnO}_{4}{ }^{-}$anions, the end products after reduction- $-\mathrm{MnO}_{2}$ and free $\mathrm{Mn}^{2+}$ ions - may also be harmful, especially as $\mathrm{Mn}^{2+}$ ions are capable of generating harmful oxygen radicals via Fenton-type chemical reactions $[58,59]$. The $\mathrm{Mn}^{2+}$ ions are essential to proper nerve cell function at physiological concentrations [60] but toxic at higher concentrations [61], resulting in a U-shaped dose-response curve for $\mathrm{Mn}^{2+}$ toxicity $[60,62]$.

The profound neurotoxicity of $\mathrm{Mn}$ is well established [63], as it is for $\mathrm{Pb}$ and $\mathrm{Cd}$, and $\mathrm{Mn}$ is considered a risk factor for ALS $[15,20]$. Elevated Mn concentrations have been found in cerebrospinal fluid from patients with ALS $[12,18]$, and in spinal cord transverse sections from deceased ALS patients [64]. The accumulation of $\mathrm{Mn}$ in the spinal cord seems to be most pronounced in the anterior horn cells [65] and lateral columns [64], which are the first to degenerate in ALS. A few cases of Parkinson-like syndromes associated with the use of intravenous $\mathrm{KMnO}_{4}$ have been described [66].
Manganese exposure from food sources has been described to contribute to ALS $[7,67,68]$, yet measurements of Mn exposures in relation to ALS are scarce. Manganese passes barriers between blood and the nervous system [69] and $\mathrm{Mn}$ affects mitochondria of ALS nerve cells [70, 71] specifically mitochondrial respiratory chain protein function and ATP production [72].

Oxidative damage to nerve tissues has been described in sporadic as well as in familiar ALS and also in other neurodegenerative diseases [7, 73-78]. In the present case, chronic oxidative damage originating from accumulated $\mathrm{Mn}^{2+}$ ions, as well as oxidative damage caused by systemic exposure to $\mathrm{MnO}_{4}{ }^{-}$anions, is presumed to represent a contributing pathogenic mechanism for the ALS observed. Exposure routes leading to metal-induced toxicity of the nervous system are varied and complex $[20,60]$. With the $\mathrm{KMnO}_{4}$ salt residing inside the well-vascularized subcutaneous tissue for several months, and possibly also in paraspinal muscles, accumulations of $\mathrm{Mn}$ in remote tissues may be expected. Body fluid or tissue manganese concentrations were however not measured for this patient. Retrograde axonal transport of $\mathrm{Mn}$ and other metals has been described in detail in both rodents [79] and humans [80]. In this case, transport of Mn from subcutaneous tissues and muscle to anterior horn cells of the spinal cord may have occurred across the blood-spinal-cord-barrier (via the bloodstream) and/or via retrograde axonal transport [80].

The average survival time from diagnosis of ALS is about 3 years [15]. In this case, a rapid disease progression was noted after exposure to $\mathrm{KMnO}_{4}$. To what extent the $\mathrm{Mn}$ exposure contributed to this rapid disease progression is unknown. We have described possible exposure routes and toxicity mechanisms for Mn. If future studies support the possibility of a causal link between Mn exposure and ALS, it might become relevant to discuss treatments against metal exposure such as chelation therapy [81-83]. Other metals with potential relevance for ALS pathogenesis are $\mathrm{Cu}, \mathrm{Al}, \mathrm{As}, \mathrm{Cd}, \mathrm{Co}, \mathrm{Zn}, \mathrm{V}$, and $U$, all of which have been found in significantly elevated concentrations in the CSF of ALS patients, compared to healthy controls $[20,21]$. Taken together, the presented findings suggest that the use of minerals and metal salts such as $\mathrm{KMnO}_{4}$ in African traditional medicine can be directly harmful to the patient are consistent with a connection between ALS, Mn exposure and oxidative damage, and highlight the risks involved in using undocumented chemicals in traditional medical practices.

\section{Conclusions}

Manganese exposure is a possible risk factor for ALS. Further studies on neurotoxic metals in ALS pathogenesis are warranted. 
Acknowledgments Open access funding provided by Karolinska Institute. We thank PhD student Cecilia Mörman and Dr. Kjell Jansson, both at Stockholm University, for assistance with the analyses of the black powder. We thank Monica Nordberg for helpful discussions. This article was published with oral and written permission from the patient's closest relatives, whom we thank also for their help with providing samples of the black powder and describing the patient's medical history.

Authors' Contributions Conceptualization, E.R., P.M.R., and S.K.T.S.W.; investigation, E.R., P.M.R., J.J., J.M., S.B.S., and S.K.T.S.W.; writing - original draft preparation, E.R., J.M., P.M.R., S.B.S., and S.K.T.S.W.; writing-review and editing, E.R., S.K.T.S.W., J.M., S.B.S., J.J., A.G., and P.M.R.; methodology; A.G., J.J., P.M.R., S.K.T.S.W.; supervision, A.G., P.M.R., and S.K.T.S.W.; project administration, P.M.R. and S.K.T.S.W.; funding acquisition, A.G., P.M.R., and S.K.T.S.W. All authors have read and agreed to the published version of the manuscript.

Funding This research work was supported by the Ulla-Carin Lindquist ALS-Foundation (P.M.R.), the Magnus Bergvall foundation (P.M.R. and S.K.T.S.W.) and the strategic grants Institute of Environmental Medicine Karolinska Institutet (P.M.R.)

\section{Compliance with ethical standards}

Conflict of Interest The authors declare no conflicts of interest. The funders had no role in the design of the study; in the collection, analyses, or interpretation of data; in the writing of the manuscript; or in the decision to publish the results.

Open Access This article is licensed under a Creative Commons Attribution 4.0 International License, which permits use, sharing, adaptation, distribution and reproduction in any medium or format, as long as you give appropriate credit to the original author(s) and the source, provide a link to the Creative Commons licence, and indicate if changes were made. The images or other third party material in this article are included in the article's Creative Commons licence, unless indicated otherwise in a credit line to the material. If material is not included in the article's Creative Commons licence and your intended use is not permitted by statutory regulation or exceeds the permitted use, you will need to obtain permission directly from the copyright holder. To view a copy of this licence, visit http://creativecommons.org/licenses/by/4.0/.

\section{References}

1. Rowland LP, Shneider NA (2001) Amyotrophic lateral sclerosis. N Engl J Med 344(22):1688-1700

2. Daube JR (2000) Electrodiagnostic studies in amyotrophic lateral sclerosis and other motor neuron disorders. Muscle Nerve 23(10): $1488-1502$

3. Fang F, Valdimarsdottir U, Bellocco R, Ronnevi LO, Sparen P, Fall $\mathrm{K}$ et al (2009) Amyotrophic lateral sclerosis in Sweden, 1991-2005. Arch Neurol 66(4):515-519

4. Arthur KC, Calvo A, Price TR, Geiger JT, Chio A, Traynor BJ (2016) Projected increase in amyotrophic lateral sclerosis from 2015 to 2040. Nat Commun 7:12408

5. Talbot K (2009) Motor neuron disease: the bare essentials. Pract Neurol 9(5):303-309

6. D'Amico E, Factor-Litvak P, Santella RM, Mitsumoto H (2013) Clinical perspective on oxidative stress in sporadic amyotrophic lateral sclerosis. Free Radic Biol Med 65:509-527
7. Bozzo F, Mirra A, Carri MT (2017) Oxidative stress and mitochondrial damage in the pathogenesis of ALS: New perspectives. Neurosci Lett 636:3-8

8. Tokuda E, Takei YI, Ohara S, Fujiwara N, Hozumi I, Furukawa Y (2019) Wild-type $\mathrm{Cu} / \mathrm{Zn}$-superoxide dismutase is misfolded in cerebrospinal fluid of sporadic amyotrophic lateral sclerosis. Mol Neurodegener 14(1):42

9. Stevens CH, Guthrie NJ, van Roijen M, Halliday GM, Ooi L (2019) Increased Tau phosphorylation in motor neurons from clinically pure sporadic amyotrophic lateral sclerosis patients. J Neuropathol Exp Neurol 78(7):605-614

10. Gonzalez-Garza MT, Martinez HR, Cruz-Vega DE, HernandezTorre M, Moreno-Cuevas JE (2018) Adipsin, MIP-1b, and IL-8 as CSF Biomarker Panels for ALS Diagnosis. Dis Markers:2018 3023826

11. Henkel JS, Engelhardt JI, Siklos L, Simpson EP, Kim SH, Pan T et al (2004) Presence of dendritic cells, MCP-1, and activated microglia/macrophages in amyotrophic lateral sclerosis spinal cord tissue. Ann Neurol 55(2):221-235

12. Roos PM, Vesterberg O, Nordberg M (2006) Metals in motor neuron diseases. Exp Biol Med 231(9):1481-1487

13. Sheykhansari S, Kozielski K, Bill J, Sitti M, Gemmati D, Zamboni P, Singh AV (2018) Redox metals homeostasis in multiple sclerosis and amyotrophic lateral sclerosis: a review. Cell Death Dis 9(3):348

14. Wallin C, Sholts SB, Österlund N, Luo J, Jarvet J, Roos PM, Ilag L, Gräslund A, Wärmländer SKTS (2017) Alzheimer's disease and cigarette smoke components: effects of nicotine, PAHs, and $\mathrm{Cd}(\mathrm{II}), \mathrm{Cr}(\mathrm{III}), \mathrm{Pb}(\mathrm{II}), \mathrm{Pb}(\mathrm{IV})$ ions on amyloid-beta peptide aggregation. Sci Rep 7(1):14423

15. Ingre C, Roos PM, Piehl F, Kamel F, Fang F (2015) Risk factors for amyotrophic lateral sclerosis. Clin Epidemiol 7:181-193

16. Sutedja NA, Veldink JH, Fischer K, Kromhout H, Heederik D, Huisman MH et al (2009) Exposure to chemicals and metals and risk of amyotrophic lateral sclerosis: a systematic review. Amyotrophic Lateral Scler 10(5-6):302-309

17. Gunnarsson LG, Bodin L (2018) Amyotrophic lateral sclerosis and occupational exposures: a systematic literature review and metaanalyses. Int J Environ Res Public Health 15(11):2371

18. Roos PM, Lierhagen S, Flaten TP, Syversen T, Vesterberg O, Nordberg M (2012) Manganese in cerebrospinal fluid and blood plasma of patients with amyotrophic lateral sclerosis. Exp Biol Med 237(7):803-810

19. Fang F, Kwee LC, Allen KD, Umbach DM, Ye W, Watson M, Keller J, Oddone EZ, Sandler DP, Schmidt S, Kamel F (2010) Association between blood lead and the risk of amyotrophic lateral sclerosis. Am J Epidemiol 171(10):1126-1133

20. Roos PM (2013) Studies on metals in motor neuron disease. In: Dissertation. Karolinska Institutet, Solna

21. Roos PM, Vesterberg O, Syversen T, Flaten TP, Nordberg M (2013) Metal concentrations in cerebrospinal fluid and blood plasma from patients with amyotrophic lateral sclerosis. Biol Trace Elem Res 151(2):159-170

22. WHO. 2019 [Available from: https://www.afro.who.int/healthtopics/traditional-medicine.

23. Street RA, Cele MP (2013) Commonly used metal and crystalline salts in South African traditional medicine. J Ethnopharmacol 148(1):329-331

24. Wärmländer SKTS, Söderberg A (2019) Hollow comb rivets made from strip-drawn copper wire and two possible antler draw plates from 11th-12th c. Sigtuna, Sweden. Fornvännen. 114(2):88-99

25. Saage R, Wärmländer SKTS (2018) Metal residues in 5th c. BCE13th c. CE Estonian tools for non-ferrous metal casting. J Archaeol Sci Rep 19:35-51

26. Wärmländer SKTS, Wåhlander L, Saage R, Rezakhani K, Hamid Hassan SA, Neiss M (2015) Analysis and interpretation of a unique 
Arabic finger ring from the Viking Age town of Birka. Sweden Scan 37(2):131-137

27. Boutrup J, Franzén ML, Wärmländer S (2013) Two 15th century openwork braids of silk and metal thread from Riddarholmen Church and Alvastra Abbey in Sweden. Fornvännen. 108(1):23-32

28. Muros V, Wärmländer SKTS, Scott DA, Theile JM (2007) Characterization of 17th-19th Century Metal Threads from the Colonial Andes. J Am Inst Conserv 46(3):229-244

29. Bartelink EJ, Sholts SB, Milligan CF, Van Deest TL, Wärmländer SKTS (2015) A Case of Contested Cremains Analyzed Through Metric and Chemical Comparison. J Forensic Sci 60(4):1068-1073

30. Scott DA, Wärmländer S, Mazurek J, Quirke S (2009) Examination of some pigments, grounds and media from Egyptian cartonnage fragments in the Petrie Museum, University College London. J Archaeol Sci 36(3):923-932

31. Smith KN, Vellanoweth RL, Sholts SB, Wärmländer SKTS (2018) Residue analysis, use-wear patterns, and replicative studies indicate that sandstone tools were used as reamers when producing shell fishhooks on San Nicolas Island, California. J Archaeologic Sci: Reports 20:502-505

32. Smith KN, Wärmländer SKTS, Vellanoweth RL, Smith CM, Kendig WE (2015) Residue analysis links sandstone abraders to shell fishhook production on San Nicolas Island, California. J Archaeologic Sci 54:287-293

33. Wärmländer SKTS, Zori D, Byock J, Scott DA (2010) Metallurgical findings from a Viking Age chieftain's farm in Iceland. J Archaeol Sci 37(9):2284-2290

34. Sauzeat L, Bernard E, Perret-Liaudet A, Quadrio I, Vighetto A, Krolak-Salmon P et al (2018) Isotopic evidence for disrupted copper metabolism in amyotrophic lateral sclerosis. iScience 6:264 271

35. Veyrat-Durebex C, Corcia P, Mucha A, Benzimra S, Mallet C, Gendrot $C$ et al (2014) Iron metabolism disturbance in a French cohort of ALS patients. Biomed Res Int 2014:485723

36. Voss K, Harris C, Ralle M, Duffy M, Murchison C, Quinn JF (2014) Modulation of tau phosphorylation by environmental copper. Transl Neurodegener 3(1):24

37. Garve R, Garve M, Turp JC, Fobil JN, Meyer CG (2017) Scarification in sub-Saharan Africa: social skin, remedy and medical import. Tropical Med Int Health 22(6):708-715

38. Gröning C (1997) Decorated Skin, A World Survey of Body Art. Thames and Hudson, London

39. Lo T, Tindall A (2012) Acute lower back pain mapped by dermatomal scarification in urban Malawi. BMJ Case Rep 2012: bcr1120103529

40. Weisz JR (1972) East African medical attitudes. Soc Sci Med (1967) 6(3):323-333

41. Street R (2012) Heavy metals in medicinal plant products - An African perspective. S Afr J Bot 82:67-74

42. Sholts S, Smith K, Wallin C, Ahmed T, Wärmländer SKTS (2017) Ancient water bottle use and polycyclic aromatic hydrocarbon $(\mathrm{PAH})$ exposure among California Indians: a prehistoric health risk assessment. Environ Health 16:61

43. Wärmländer SKTS, Sholts S, Erlandson J, Gjerdrum T, Westerholm R (2011) Could the health decline of prehistoric California Indians be related to exposure to polycyclic aromatic hydrocarbons (PAHs) from Natural Bitumen? Environ Health Perspect 119(9):1203-1207

44. Wanzala W, Walingo M (2019) Ethnomedicines and Health Management in Kenya: Which Way Forward? J Complement Med Alternat Healthcare 10(3):1-14

45. Harrington $\mathbf{J}$ (2018) Governing traditional medicine in Kenya: problematization and the role of the constitution. Afr Stud 77(2): 223-239

46. WHO. World Health Organization Model List of Essential Medicines. 2019.
47. WHO. WHO model prescribing information: drugs used in skin diseases. 1997.

48. Hugo WB (1991) A brief history of heat and chemical preservation and disinfection. J Appl Bacteriol 71(1):9-18

49. Street RA, Kabera GM, Connolly C (2018) Ethnopharmacological use of potassium permanganate in South African traditional medicine. South Afr Med J 108(3):187-189

50. Balme KH, Roberts JC, Glasstone M, Curling L, Mann MD (2012) The changing trends of childhood poisoning at a tertiary children's hospital in South Africa. South Afr Med J 102(3 Pt 1):142-146

51. Lewis HH, Cronje RE, Naude SP, van den Berg C (1989) Accidental poisoning in childhood. South Afr Med J 76(8):429 431

52. Malangu N, Ogunbanjo GA (2009) A profile of acute poisoning at selected hospitals in South Africa. South Afr J Epidemiol Infect 24(2):14-16

53. Segal I, Tim LO, Hamilton DG, Lawson HH, Solomon A, Kalk F, Cooke SAR (1979) Ritual-enema-induced colitis. Dis Colon Rectum 22(3):195-199

54. Ladbury JW, Cullis CF (1958) Kinetics And Mechanism Of Oxidation By Permanganate. Chem Rev 58(2):403-438

55. Agrawal VK, Bansal A, Kumar R, Kumawat BL, Mahajan P (2014) Potassium permanganate toxicity: A rare case with difficult airway management and hepatic damage. Indian J Crit Care Med 18(12): 819-821

56. Middleton SJ, Jacyna M, McClaren D, Robinson R, Thomas HC (1990) Haemorrhagic pancreatitis-a cause of death in severe potassium permanganate poisoning. Postgrad Med J 66(778):657-658

57. Ong KL, Tan TH, Cheung WL (1997) Potassium permanganate poisoning-a rare cause of fatal self poisoning. J Accid Emerg Med 14(1):43-45

58. Bokare AD, Choi W (2014) Review of iron-free Fenton-like systems for activating $\mathrm{H} 2 \mathrm{O} 2$ in advanced oxidation processes. J Hazard Mater 275:121-135

59. Wallin C, Kulkarni YS, Abelein A, Jarvet J, Liao Q, Strodel B, Olsson L, Luo J, Abrahams JP, Sholts SB, Roos PM, Kamerlin SCL, Gräslund A, Wärmländer SKTS (2016) Characterization of $\mathrm{Mn}(\mathrm{II})$ ion binding to the amyloid-beta peptide in Alzheimer's disease. J Trace Elem Med Biol 38:183-193

60. Nordberg G, Fowler B, Nordberg M (2015) Handbook on the Toxicology of Metals, 4th edn. Elsevier, Amsterdam, pp 1-1542

61. Aschner M, Aschner JL (1991) Manganese neurotoxicity: cellular effects and blood-brain barrier transport. Neurosci Biobehav Rev 15(3):333-340

62. Milton B, Krewski D, Mattison DR, Karyakina NA, Ramoju S, Shilnikova N, Birkett N, Farrell PJ, McGough D (2017) Modeling U-shaped dose-response curves for manganese using categorical regression. Neurotoxicology. 58:217-225

63. Lucchini RG, Aschner M, Landrigan PJ, Cranmer JM (2018) Neurotoxicity of manganese: Indications for future research and public health intervention from the Manganese 2016 conference. Neurotoxicology. 64:1-4

64. Miyata S, Nakamura S, Nagata H, Kameyama M (1983) Increased manganese level in spinal cords of amyotrophic lateral sclerosis determined by radiochemical neutron activation analysis. J Neurol Sci 61(2):283-293

65. Kihira T, Mukoyama M, Ando K, Yase Y, Yasui M (1990) Determination of manganese concentrations in the spinal cords from amyotrophic lateral sclerosis patients by inductively coupled plasma emission spectroscopy. J Neurol Sci 98(2-3):251-258

66. Meral H, Kutukcu Y, Atmaca B, Ozer F, Hamamcioglu K (2007) Parkinsonism caused by chronic usage of intravenous potassium permanganate. Neurologist 13(2):92-94

67. Iwami O, Watanabe T, Moon CS, Nakatsuka H, Ikeda M (1994) Motor neuron disease on the Kii Peninsula of Japan: excess 
manganese intake from food coupled with low magnesium in drinking water as a risk factor. Sci Total Environ 149(1-2):121-135

68. Greco V, Longone P, Spalloni A, Pieroni L, Urbani A (2019) Crosstalk between oxidative stress and mitochondrial damage: focus on amyotrophic lateral sclerosis. Adv Exp Med Biol 1158:7182

69. Zheng W (2001) Toxicology of choroid plexus: special reference to metal-induced neurotoxicities. Microsc Res Tech 52(1):89-103

70. Smith EF, Shaw PJ, De Vos KJ (2019) The role of mitochondria in amyotrophic lateral sclerosis. Neurosci Lett 710:132933

71. Harischandra DS, Ghaisas S, Zenitsky G, Jin H, Kanthasamy A, Anantharam V, Kanthasamy AG (2019) Manganese-induced neurotoxicity: new insights into the triad of protein misfolding, mitochondrial impairment, and neuroinflammation. Front Neurosci 13: 654

72. Wiedemann FR, Manfredi G, Mawrin C, Beal MF, Schon EA (2002) Mitochondrial DNA and respiratory chain function in spinal cords of ALS patients. J Neurochem 80(4):616-625

73. Barber SC, Shaw PJ (2010) Oxidative stress in ALS: key role in motor neuron injury and therapeutic target. Free Radic Biol Med 48(5):629-641

74. Blasco H, Garcon G, Patin F, Veyrat-Durebex C, Boyer J, Devos D, Vourc'h P, Andres CR, Corcia P (2017) Panel of oxidative stress and inflammatory biomarkers in ALS: A Pilot Study. Can J Neurol Sci 44(1):90-95

75. Carri MT, Valle C, Bozzo F, Cozzolino M (2015) Oxidative stress and mitochondrial damage: importance in non-SOD1 ALS. Front Cell Neurosci 9:41
76. Chen Z, Zhong C (2014) Oxidative stress in Alzheimer's disease. Neurosci Bull 30(2):271-281

77. Simon DK, Tanner CM, Brundin P (2020) Parkinson disease epidemiology, pathology, genetics, and pathophysiology. Clin Geriatr Med 36(1):1-12

78. Wärmländer SKTS, Österlund N, Wallin C, Wu J, Luo J, Tiiman A, Jarvet J, Gräslund A (2019) Metal binding to the amyloid-beta peptides in the presence of biomembranes: potential mechanisms of cell toxicity. J Biol Inorg Chem 24(8):1189-1196

79. Henriksson J, Tallkvist J, Tjalve H (1999) Transport of manganese via the olfactory pathway in rats: dosage dependency of the uptake and subcellular distribution of the metal in the olfactory epithelium and the brain. Toxicol Appl Pharmacol 156(2):119-128

80. Arvidson B (1994) A review of axonal transport of metals. Toxicology. 88(1-3):1-14

81. Mangelsdorf I, Walach H, Mutter J (2017) Healing of amyotrophic lateral sclerosis: a case report. Complement Med Res 24(3):175181

82. Aaseth J, Crisponi G, Andersen O. Chelation therapy in the treatment of metal intoxication: Academic Press; 2016.

83. Cao Y, Skaug MA, Andersen O, Aaseth J (2015) Chelation therapy in intoxications with mercury, lead and copper. J Trace Elem Med Biol 31:188-192

Publisher's Note Springer Nature remains neutral with regard to jurisdictional claims in published maps and institutional affiliations. 